This is the peer reviewed version of the following article: Eur. J. Inorg. Chem. 2011, 4464-4470,

which has been published in final form at: https://doi.org/10.1002/ejic.201100685

FULL PAPER

DOI: 10.1002/ejic.200((will be filled in by the editorial staff))

\title{
Synthesis and X-Ray Crystal Structures of Multinuclear Zincamidinate Complexes
}

\author{
Sarah Schmidt, ${ }^{[\mathrm{a}]}$ Benjamin Gutschank, ${ }^{[\mathrm{a}]}$ Stephan Schulz, ${ }^{[\mathrm{a}] *}$ Dieter Bläser, ${ }^{[\mathrm{a}]}$ Roland Boese, ${ }^{[\mathrm{a}]}$ \\ Christoph Wölper
}

Keywords: N ligands / Zinc / X-Ray crystal structure

\begin{abstract}
Reactions of $\mathrm{Me}_{2} \mathrm{Zn}$ with carbodiimides $\mathrm{RN}=\mathrm{C}=\mathrm{NR}(\mathrm{R}=\mathrm{Et}, \mathrm{Ph})$ yielded polynuclear amidinate zinc complexes $\left\{[\mathrm{MeZn}]_{4}\left[\mathrm{C}(\mathrm{RNCNR})_{4}\right]\right\} \quad(\mathrm{R}=\mathrm{Et} \quad \mathbf{1}, \quad \mathrm{Ph}$ 3) and $\left\{[\mathrm{MeZn}]_{2}\left[\mathrm{C}(\mathrm{EtNCNEt})_{2}\left(\mathrm{C}_{2}(\mathrm{NEt})_{3}\right)\right]\right\}$ 2. In addition, the reaction of $\left\{[\mathrm{ClZn}]_{4}\left[\mathrm{C}(i-\mathrm{PrNCN} i-\mathrm{Pr})_{4}\right]\right\}$ with $\mathrm{MCl}_{3}$ gave the corresponding Lewis acid-base adducts $\left\{\left[\mathrm{MCl}_{3}\right]_{2}[\mathrm{ClZn}]_{4}\left[\mathrm{C}(i-\operatorname{PrNCN} i-\mathrm{Pr})_{4}\right]\right\}(\mathrm{M}=$

[a] Institute of Inorganic Chemistry, University of Duisburg-Essen, 45117 Essen, Germany

Fax: + 49 0201-1834635

E-mail: stephan.schulz@uni-due.de
\end{abstract}

\section{Introduction}

$\mathrm{N}, \mathrm{N}^{\prime}$-chelating organic ligands such as $\beta$-diketiminate, ${ }^{[1]}$ guanidinate $^{[2]}$ and amidinate anions ${ }^{[3]}$ are well known in coordination chemistry of s-, p-, d- and f-block metals. ${ }^{[4]}$ Their flexible binding modes (monodentate $\eta^{l}$, chelating $\eta^{2}$, bridging monodentate $\mu-\eta^{l}-\eta^{l}$ ) and tunable steric and electronic properties render them promising candidates for the synthesis of tailor-made complexes with potential technical applications in catalysis ${ }^{[5]}$ and in material sciences (i.e. CVD precursor). ${ }^{[6]}$<smiles>[M]C1CCCNCC1</smiles>
$\eta^{1}$<smiles>[M]1NCCCNN1</smiles>

$\eta^{2}$

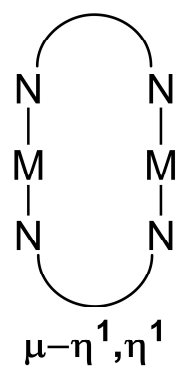

Scheme 1. Typical binding modes of N,N'-chelating ligands.

Considering the long history of metal amidinate complexes in main group and transition metal chemistry, it came to us as a surprise that zinc amidinate complexes have been structurally characterized to a far lesser extent. ${ }^{[7]}$ In contrast, guanidinate complexes $^{[8]}$ and $\beta$-diketiminate complexes, ${ }^{\left[{ }^{[]}\right.}$which have been used in ROP polymerization of lactide and the copolymerization of epoxides and carbon dioxide, have been studied in more detail. We therefore became interested in this specific class of compounds and reported on the synthesis of mono- and bisamidinate complexes of the type $\mathrm{LZnX}$ and $\mathrm{L}_{2} \mathrm{Zn}(\mathrm{L}=$ amidinate), which were obtained from salt elimination reactions between $\mathrm{ZnX}_{2}$ and the corresponding lithium amidinate complex. ${ }^{[10]}$ Moreover, reactions

\author{
$\mathrm{Al} \mathrm{4,} \mathrm{Ga} \mathrm{5).} 1-5$ were characterized by multinuclear NMR $\left({ }^{1} \mathrm{H}\right.$, \\ ${ }^{13} \mathrm{C}$ ) and IR spectroscopy, elemental analyses and by single \\ crystal X-ray diffraction.
}

(C) WILEY-VCH Verlag GmbH \& Co. KGaA, 69451 Weinheim, Germany, 2009)

of carbodiimides $\mathrm{RN}=\mathrm{C}=\mathrm{NR}$ with $\mathrm{ZnR}_{2}$, which were expected to proceed with insertion of the carbodiimide into the zinc-carbon bond and formation of the corresponding amidinate complexes $\left[\mathrm{R}^{\prime} \mathrm{ZnNRC}\left(\mathrm{R}^{\prime}\right) \mathrm{NR}\right]_{\mathrm{x}}{ }^{[11]}$ were investigated. While the reaction of $\mathrm{ZnEt}_{2}$ with di(isopropyl)carbodiimide gave the expected dimeric amidinate complex $\left[\mathrm{EtC}(\mathrm{N} i-\mathrm{Pr})_{2} \mathrm{ZnEt}\right]_{2},{ }^{[12]}$ in which the amidinate units serve as $\mu-\eta^{1}, \eta^{1}$-bridging moieties, multinuclear zinc amidinate complexes such as $\left\{[\mathrm{MeZn}]_{4}\left[\mathrm{C}(\mathrm{RNCNR})_{4}\right]\right\} \quad(\mathrm{R}=i$ $\left.\operatorname{Pr},{ }^{[13]} \mathrm{Cy}^{[14]}\right)$ were unexpectedly formed in the reaction with $\mathrm{ZnMe}_{2}$, whereas no reactions were observed with sterically hindered carbodiimides $\left(\mathrm{R}=t\right.$ - $\mathrm{Bu}, \mathrm{SiMe}_{3}$, Dipp).
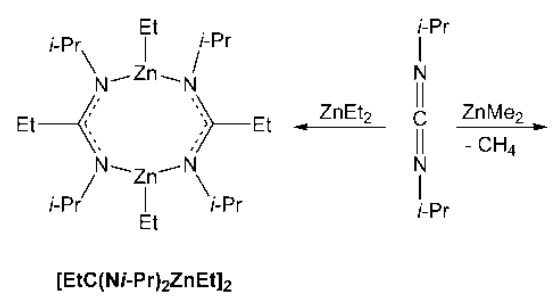

$\left[\mathrm{EtC}(\mathrm{N} i-\mathrm{Pr})_{2} \mathrm{ZnEt}\right]_{2}$

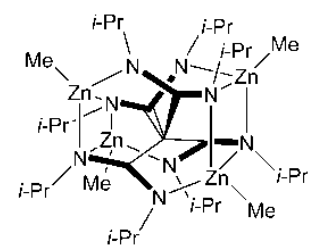

$\left\{\mathrm{C}\left[\mathrm{C}(\mathrm{Ni}-\mathrm{Pr})_{2} \mathrm{ZnMe}\right]_{4}\right\}$

Scheme 2. Synthesis of zincamidinate complexes by carbodiimide insertion reaction.

These reactions, which proceeded with $\mathrm{C}-\mathrm{H}$ activation and $\mathrm{C}-\mathrm{C}$ bond formation, are without precedent in carbodiimide chemistry. In order to further clarify the role of the N-bonded substituent R' of the carbodiimide and to verify both steric and electronic influences, we studied reactions of $\mathrm{ZnMe}_{2}$ with carbodiimides $\mathrm{R}^{\prime} \mathrm{N}=\mathrm{C}=\mathrm{NR}^{\prime}$ in more detail. Herein, we report on the reactions of $\mathrm{ZnMe}_{2}$ with di(ethyl)carbodiimide and di(phenyl)carbodiimide, yielding the polynuclear zincamidinate complexes $\left\{[\mathrm{MeZn}]_{4}\left[\mathrm{C}(\mathrm{RNCNR})_{4}\right]\right\}$ (R $=\mathrm{Et} \mathbf{1}, \mathrm{Ph}$ 3) and $\left\{[\mathrm{MeZn}]_{2}\left[\mathrm{C}(\mathrm{EtNCNEt})_{2}\left(\mathrm{C}_{2}(\mathrm{NEt})_{3}\right)\right]\right\} \quad \mathbf{2}$, respectively. Moreover, reactions of the $\mathrm{Cl}$-substituted tetranuclear complex $\left\{[\mathrm{ClZn}]_{4}\left[\mathrm{C}(i-\mathrm{PrNCN} i-\mathrm{Pr})_{4}\right]\right\}$ with $\mathrm{MCl}_{3}(\mathrm{M}=\mathrm{Al}, \mathrm{Ga})$ resulted in the formation of the Lewis acid-base adducts $\left\{\left[\mathrm{MCl}_{3}\right]_{2}[\mathrm{ClZn}]_{4}\left[\mathrm{C}(i-\mathrm{PrNCN} i-\mathrm{Pr})_{4}\right]\right\}(\mathrm{M}=\mathrm{Al}$ 4, Ga 5), respectively.

\section{Results and Discussion}


Equimolar amounts of $\mathrm{ZnMe}_{2}$ and $\mathrm{RN}=\mathrm{C}=\mathrm{NR}(\mathrm{R}=\mathrm{Et}, \mathrm{Ph})$ were stirred at $90{ }^{\circ} \mathrm{C}$ for $48 \mathrm{~h}$, yielding colorless crystalline solids. The reaction with $\mathrm{C}(\mathrm{NEt})_{2}$ yielded a mixture of $\left\{[\mathrm{MeZn}]_{4}[\mathrm{C}(\mathrm{EtNC}\right.$ $\left.\left.\mathrm{NEt})_{4}\right]\right\} \quad \mathbf{1}$ and $\left\{[\mathrm{MeZn}]_{2}\left[\mathrm{C}(\mathrm{EtNCNEt})_{2}\left(\mathrm{C}_{2}(\mathrm{NEt})_{3}\right)\right]\right\} \quad \mathbf{2}$ as was observed for the reactions with $\mathrm{C}(\mathrm{N} i-\mathrm{Pr})_{2}$ and $\mathrm{C}(\mathrm{NCy})_{2}$, respectively, whereas the reaction with $\mathrm{C}(\mathrm{NPh})_{2}$ exclusively gave $\left\{[\mathrm{MeZn}]_{4}\left[\mathrm{C}(\mathrm{PhNCNPh})_{4}\right]\right\} \mathbf{3}$ in almost quantitative yield. $\mathbf{1}$ and $\mathbf{2}$ were separated by fractional crystallization from toluene (1).

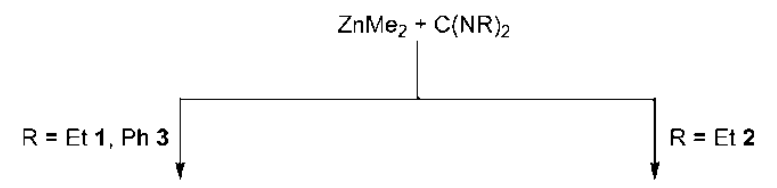

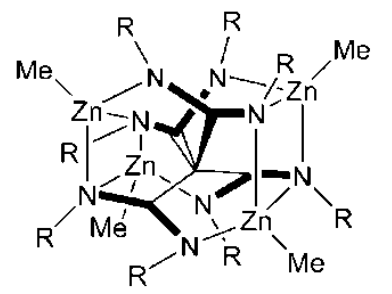

$\left\{\mathrm{C}\left[\mathrm{C}(\mathrm{NR})_{2} \mathrm{ZnMe}\right]_{4}\right\}$

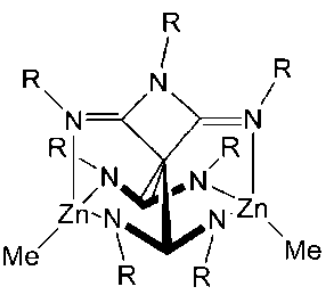

$\left\{\mathrm{C}\left[\mathrm{C}(\mathrm{NR})_{2}\right]_{2} \mathrm{Zn}_{2} \mathrm{Me}_{2}\left[\mathrm{C}_{2}(\mathrm{NR})_{3}\right]\right\}$
Scheme 3. Synthesis of $\mathbf{1}-\mathbf{3}$.

Even though the reactions of $\mathrm{ZnMe}_{2}$ and $\mathrm{C}(\mathrm{NEt})_{2}$ generally yielded a product mixture of $\mathbf{1}$ and $\mathbf{2}$ as was shown by ${ }^{1} \mathrm{H}$ NMR spectroscopy, the relative amounts of $\mathbf{1}$ and $\mathbf{2}$ within this mixture can be controlled to some extent by variation of the reaction temperature, reaction time and the $\mathrm{ZnMe}_{2} / \mathrm{C}(\mathrm{NEt})_{2}$ molar ratio. $\mathbf{1}$ is preferably formed at $90{ }^{\circ} \mathrm{C}$ and a molar ratio of $1: 1$ with about $80 \%$ yield according to ${ }^{1} \mathrm{H}$ NMR of the raw-product and $56 \%$ yield (isolated crystals) after re-crystallization, whereas an excess of the carbodiimide gave 2 in larger amounts (65\% of the rawproduct; $47 \%$ after re-crystallization). Analogous trends have been previously observed for the reaction of $\mathrm{ZnMe}_{2}$ with $\mathrm{C}(\mathrm{N} i-\mathrm{Pr})_{2}$ and $\mathrm{C}(\mathrm{NCy}) 2$, respectively. ${ }^{[14]}$

${ }^{1} \mathrm{H}$ and ${ }^{13} \mathrm{C}\left\{{ }^{1} \mathrm{H}\right\}$ NMR spectra of $\mathbf{1}$ and $\mathbf{3}$ each show a single resonance for the $\mathrm{Zn}-\mathrm{Me}$ group. The ${ }^{1} \mathrm{H}$ NMR spectrum of 1 also shows two triplets and two quartets of the nonequivalent Et groups with equal relative intensities, whereas for $\mathbf{3}$ only one additional multiplet is observed. In addition, for $\mathbf{2}$ a relative intensity of the $\mathrm{Zn}-\mathrm{Me}$ and Et groups of 2:3 is observed.

Single crystals of $\mathbf{1}, \mathbf{2}$, and $\mathbf{3}$ were obtained from solutions in pentane (1), $n$-hexane (2) and toluene (3) after storage at $-30{ }^{\circ} \mathrm{C} .1$ and 3 each contain a central, $\mathrm{sp}^{3}$-hydrized $\mathrm{C}$ atom $(\mathrm{C} 1)$, which is tetrahedrally coordinated by four $\mathrm{C}$ atoms of adjacent amidinate groups, hence resulting in the formation of a tetraamidinate ligand system. Each amidinate group coordinates to the $\mathrm{Zn}$ atoms in a $\mu$ $\eta^{l}, \eta^{l}$-bridging fashion. The cluster-type structures are therefore best described as two eight-membered $\mathrm{Zn}_{2}(\mathrm{NCN})_{2}$ rings (top and bottom half of the cluster in fig. 1 and 3 , respectively), which are connected by the central carbon atom $(\mathrm{C} 1)$. Each $\mathrm{Zn}$ atom also binds to a methyl group and is intramolecularly coordinated by an additional $\mathrm{N}$ atom of the other eight-membered ring, hence resulting in tetrahedral coordination geometries.

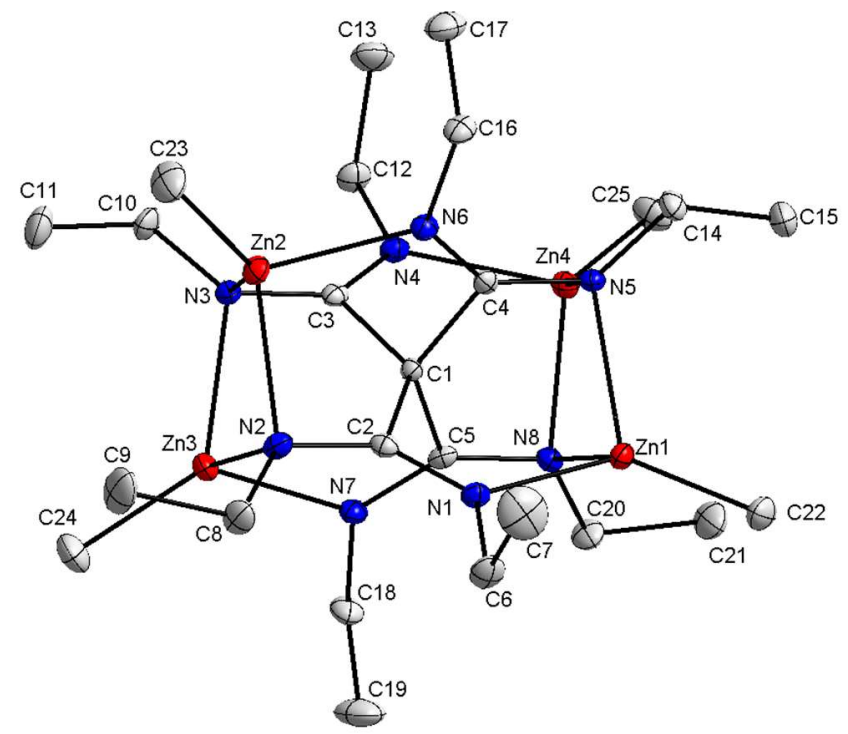

Figure 1. Solid state structure of $\mathbf{1}$ (thermal ellipsoids are shown at $50 \%$ probability levels); $\mathrm{H}$ atoms are omitted for clarity; Me and $\mathrm{Cy}$ groups are presented in a diminished fashion. Selected bond lengths $[\AA]$ and angles $\left[{ }^{\circ}\right]$ : Zn1-N1 2.1241(11), Zn1-N8 2.1285(11), Zn1-N5 2.1783(10), Zn2-N2 2.1541(11), Zn2-N3 2.1749(11), Zn2-N6 2.1195(11), Zn3-N2 2.1596(12), Zn3-N3 2.1457(11), Zn3-N7 2.1242(11), Zn4-N4 2.1220(11), Zn4-N5 2.1383(10), Zn4-N8 2.1666(11), Zn1-C22 1.9650(14), N1-C2 1.3087(16), N2-C2 1.3558(16), N3-C3 1.3525(16), N4-C3 1.3056(16), C1-C2 1.5503(17), C1-C3 1.5495(17), C1-C4 1.5473(18), C1-C5 1.5504(17); N1Zn1-N8 95.84(4), N1-Zn1-N5 97.22(4), N5-Zn1-N8 82.31(4), N2-Zn2-N6 96.98(4), N3-Zn2-N6 96.47(4), N2-Zn2-N3 81.96(4), N1-C2-N2 137.02(12), N3-C3-N4 136.32(12), C2-C1-C3 129.46(10), C2-C1-C4 101.16(9), C3-C1-C4 100.60(9), C2-C1-C5 99.95(9), C3-C1-C5 100.30(9).

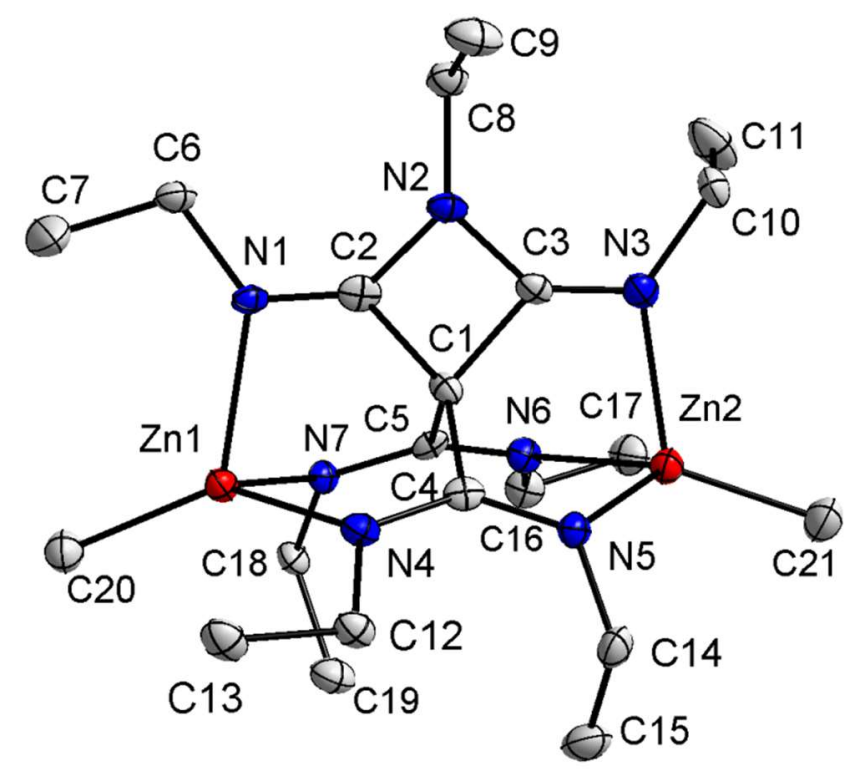

Figure 2. Solid state structure of complex 2 (thermal ellipsoids are shown at $50 \%$ probability levels); $\mathrm{H}$ atoms are omitted for clarity; Me and $\mathrm{Cy}$ groups are presented in a diminished fashion. Selected bond lengths $[\AA]$ and angles $\left[^{\circ}\right]$ : Zn1-N1 2.165(3), Zn1-N4 2.075(3), Zn1-N7 2.115(3), Zn2-N3 2.135(3), Zn2-N5 2.094(3), Zn2-N6 2.099(3), N1-C2 1.259(4), N2-C2 1.398(4), N2C3 1.399(4), N3-C3 1.256(4), N4-C4 1.335(4), N5-C4 1.311(4), N6-C5 1.300(4), N7-C5 1.338(4), C1-C2 1.515(5), C1-C3 1.532(5), C1-C4 1.532(5), C1-C5 1.542(5); N1-Zn1-N4 90.62(11), N4-Zn1-N7 95.55(10), N1-Zn1-N7 90.87(10), N5-Zn2-N6 94.42(11), N3-Zn2-N5 91.72(11), N3Zn2-N6 89.69(11), N1-C2-N2 138.0(3), N2-C3-N3 139.4(3), N4-C4-N5 138.2(3), N6-C5-N7 137.2(3), C2-C1-C3 83.4(2), C2-C1-C4 118.9(3), C3C1-C4 117.7(3), C2-C1-C5 117.2(3), C3-C1-C5 116.2(3). 


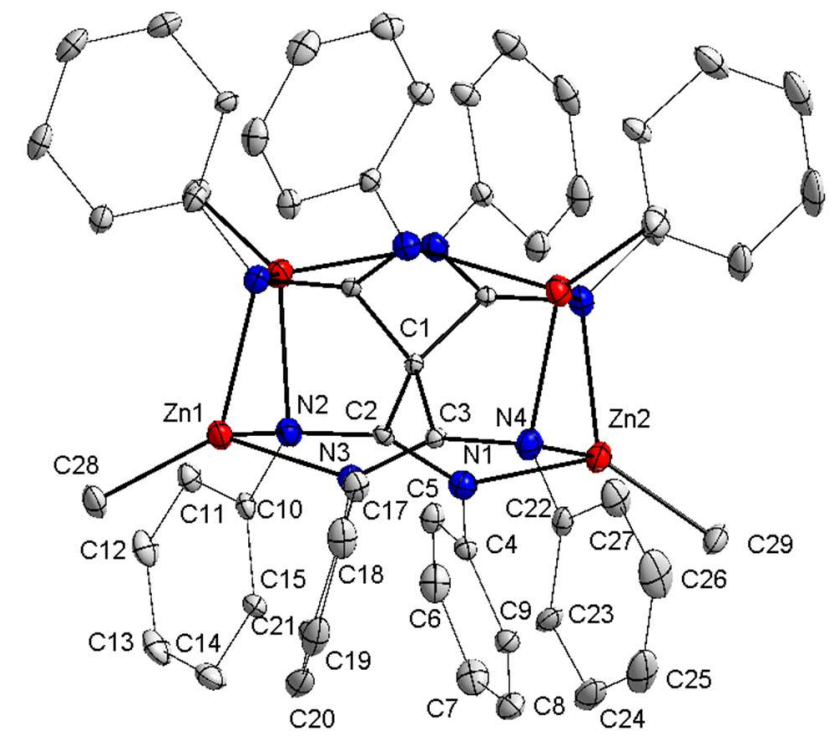

Figure 3. Solid state structure of $\mathbf{3}$ (thermal ellipsoids are shown at $50 \%$ probability levels); $\mathrm{H}$ atoms are omitted and thermal ellipsoids of the $\mathrm{Me}$ and $\mathrm{Ph}$ groups are shown at $10 \%$ probability levels for clarity. Selected bond lengths $[\AA]$ and angles $\left[^{\circ}\right]$ : Zn1-N2 2.1735(16), Zn1-N3 2.1433(17), Zn1-N2a 2.1886(16), Zn2-N1 2.1509(17), Zn2-N4 2.1332(17), Zn2-N4a $2.2338(17), \mathrm{N} 1-\mathrm{C} 2$ 1.314(3), N2-C2 1.340(3), N3-C3 1.312(2), N4-C3 1.341(3), C1-C2 1.544(2), C1-C3 1.544(2); N2-Zn1-N3 95.76(6), N2a-Zn1N3 94.36(6), N2-Zn1-N2a 80.59(7), N1-Zn2-N4 95.02(6), N1-Zn2-N4a $95.08(6), \quad \mathrm{N} 4-\mathrm{Zn} 2-\mathrm{N} 4 \mathrm{a} \quad 81.67(7), \quad \mathrm{N} 1-\mathrm{C} 2-\mathrm{N} 2 \quad 136.07(18), \quad \mathrm{N} 3-\mathrm{C} 3-\mathrm{N} 4$ 135.32(18), C2-C1-C3 100.22(9), C2-C1-C3a 100.93(9), C3-C1-C3a 129.4(2), C2-C1-C2a 129.1(2). a: $-\mathrm{x}+1, \mathrm{y},-\mathrm{z}+1 / 2$

The equal $\mathrm{C}-\mathrm{C}$ bond lengths within the central $\mathrm{CC}_{4}$ moieties (average values: 1 1.549(2) $\AA, 3$ 1.544(2) $\AA$ ) clearly prove the formation of $\mathrm{C}-\mathrm{C}$ single bonds. The $\mathrm{Zn}-\mathrm{N}$ bond lengths in 1 (2.1195(11)-2.1783(10) $\AA$ ) are comparable to those of the isopropyl- (2.108(2)-2.134(2) $\AA$ ) and cyclohexyl-substituted complexes (2.141(3)-2.180(3) $\AA$ ) whereas the range observed for 3 (2.1332(17)-2.2339(17) $\AA$ ) is much larger, in particular the Zn2aN4 bond lengths of $2.2339(17) \AA$ are significantly elongated. The $\mathrm{N}-\mathrm{C}$ bond lengths of the threefold-coordinated $\mathrm{N}$ atoms (1: N1-C2 1.3087(16), N4-C3 1.3056(16), N6-C4 1.3066(16), N7-C5 1.3042(17); 3: N1-C2 1.314(3), N3-C3 1.312(2) A) within the amidinate $\mathrm{NCN}$ backbone are slightly shorter compared to those of the fourfold-coordinated $\mathrm{N}$ atoms (1: N2-C2 1.3558(16), N3-C3 1.3525(16), N5-C4 1.3565(16), N8-C5 1.3573(16); 3: N2-C2 $1.340(3), \mathrm{N} 4-\mathrm{C} 3$ 1.341(3) $\AA$ ), indicating that the $\pi$-electron systems are not perfectly delocalized. The $\mathrm{Zn}-\mathrm{C}$ bond lengths of 1 (1.9650(14) $\AA, 1.9681(15) \AA, 1.9658(15) \AA, 1.9649(13) \AA)$ and 3 (1.951(2) $\AA, 1.946(2) \AA)$ are within the typical range observed for Zn-Me bonds.

In 2 , the central $\mathrm{C} 1$ atom binds to two $\mathrm{sp}^{2}$-hybridized $\mathrm{C}$ atoms $(\mathrm{C} 4, \mathrm{C} 5)$ of adjacent amidinate moieties and two carbon atoms of a $\mathrm{NCNCN}$ unit $(\mathrm{C} 2, \mathrm{C} 3)$ in a tetrahedral coordination mode as was previously observed for $\left\{[\mathrm{MeZn}]_{2}\left[\mathrm{C}(i-\mathrm{PrNCN} i-\mathrm{Pr})_{2}\left(\mathrm{C}_{2}(\mathrm{~N} i-\right.\right.\right.$ $\left.\left.\left.\mathrm{Pr})_{3}\right)\right]\right\} .{ }^{13}$ The C-C bond lengths in 2 (1.524(2)-1.547(2) $\AA$ ) are comparable to those previously observed for multinuclear complexes of this type. The two amidinate groups adopt $\mu-\eta^{l}, \eta^{l}$ bridging positions between two $\mathrm{Zn}$ atoms, hence forming an eightmembered $\left[\mathrm{Zn}_{2}(\mu-\mathrm{NCN})_{2}\right]$ heterocycle. The N-C bond lengths within the NCNCN unit, which is most-likely formed via intermediate formation of a guanidinate unit and elimination of $\mathrm{RN}(\mathrm{ZnMe})_{2}$ as was described previously,${ }^{14}$ significantly differ. The bond lengths of the terminal C-N bonds (N1-C2 1.259(4), N3-C3 $1.256(4) \AA$ ) are typical for a $\mathrm{C}=\mathrm{N}$ double bond whereas those of the inner C-N-C unit (N2-C2 1.398(4), N2-C3 1.399(4) Å) are in the range typically observed for $\mathrm{C}-\mathrm{N}$ single bonds. These distances clearly show that the $\pi$-electrons within the $\mathrm{N}=\mathrm{C}-\mathrm{N}-\mathrm{C}=\mathrm{N}$ moiety are fully localized. In contrast, the $\mathrm{C}-\mathrm{N}$ bond lengths within the eight-membered $\left[\mathrm{Zn}_{2}(\mu-\mathrm{NCN})_{2}\right]$ ring of $2(\mathrm{~N} 4-\mathrm{C} 41.335(4), \mathrm{N} 5$ C4 1.311(4), N6-C5 1.300(4), N7-C5 1.338(4) A) are similar, indicating a delocalized $\pi$-electron system. Comparable findings have been reported for $\left\{[\mathrm{MeZn}]_{2}\left[\mathrm{C}(i-\mathrm{PrNCN} i-\mathrm{Pr})_{2}\left(\mathrm{C}_{2}(\mathrm{~N} i-\mathrm{Pr})_{3}\right)\right]\right\} .{ }^{13}$

The formation of $\mathbf{1}$ and $\mathbf{3}$ clearly prove that multinuclear zinc amidinate complexes can generally be prepared by reaction of $\mathrm{ZnMe}_{2}$ with sterically less demanding carbodiimides. In order to clarify, whether the presence of electron withdrawing groups bound to the $\mathrm{N}$ atoms more selectively yield tetranuclear zinc amidinate complexes $\left\{[\mathrm{MeZn}]_{4}\left[\mathrm{C}(\mathrm{RNCNR})_{4}\right]\right\}$ as was observed for the reaction of $\mathrm{ZnMe}_{2}$ with $\mathrm{PhN}=\mathrm{C}=\mathrm{NPh}$, in which 3 was obtained in almost quantitative yield without the formation of any by-products as was typically observed in reactions with di(alkyl)carbodiimides, the reactions have to be extended to other carbodiimides containing perfluorated substituents such as $\mathrm{CF}_{3}$ and $\mathrm{C}_{6} \mathrm{~F}_{5}$.

Reactions of tetranuclear complexes $\left\{[\mathrm{MeZn}]_{4}\left[\mathrm{C}(\mathrm{RNCNR})_{4}\right]\right\}$ $(\mathrm{R}=i$ - $\mathrm{Pr}, \mathrm{Et}, \mathrm{Ph})$ with $\mathrm{O}-\mathrm{H}$ and $\mathrm{N}-\mathrm{H}$ acidic alcohols and amines failed to give the expected alkoxides and amides, respectively. These findings clearly reveal that the nucleophilicity of the Me group is rather low. We therefore became interested in halidesubstituted complexes of the general type $\left\{[\mathrm{XZn}]_{4}\left[\mathrm{C}(\mathrm{RNCNR})_{4}\right]\right\}$, which were expected to be promising starting reagents for salt metathesis reactions. ${ }^{15}$ Moreover, (multi)cationic complexes may be accessible as well. However, while $\left\{[\mathrm{MeZn}]_{4}[\mathrm{C}(i-\mathrm{PrNCN} i-\right.$ $\left.\left.\mathrm{Pr})_{4}\right]\right\}$ was found to react cleanly with aluminum halides $\mathrm{AlX}_{3}(\mathrm{X}=$ $\mathrm{Cl}, \mathrm{Br}, \mathrm{I})$ with formation of $\left\{[\mathrm{XZn}]_{4}\left[\mathrm{C}(i \text {-PrNCNi-Pr})_{4}\right]\right\},{ }^{16}$ reactions of $\mathbf{1}$ and $\mathbf{3}$ with $\mathrm{AlX}_{3}$ failed to give the expected complexes $\left\{[\mathrm{XZn}]_{4}\left[\mathrm{C}(\mathrm{RNCNR})_{4}\right]\right\}(\mathrm{R}=\mathrm{Et}, \mathrm{Ph} ; \mathrm{X}=\mathrm{Cl}, \mathrm{Br}, \mathrm{I})$. We therefore investigated reactions of $\left\{[\mathrm{ClZn}]_{4}\left[\mathrm{C}(i-\mathrm{PrNCN} i-\mathrm{Pr})_{4}\right]\right\}$ with halide abstraction reagents such as $\mathrm{AgPF}_{6}$ and $\mathrm{AgOTf}(\mathrm{Tf}=$ $\mathrm{OSO}_{2} \mathrm{CF}_{3}$ ), but these only yielded insoluble precipitates, which couldn't be characterized in more detail, to date. In contrast, reactions of $\left\{[\mathrm{ClZn}]_{4}\left[\mathrm{C}(i-\mathrm{PrNCN} i-\mathrm{Pr})_{4}\right]\right\}$ with two equivalents of $\mathrm{AlCl}_{3}$ and $\mathrm{GaCl}_{3}$ yielded the corresponding Lewis acid-base adducts $\left\{\left[\mathrm{MCl}_{3}\right]_{2}[\mathrm{ClZn}]_{4}\left[\mathrm{C}(i-\operatorname{PrNCN} i-\mathrm{Pr})_{4}\right]\right\}(\mathrm{M}=\mathrm{Al} 4, \mathrm{Ga} 5)$.

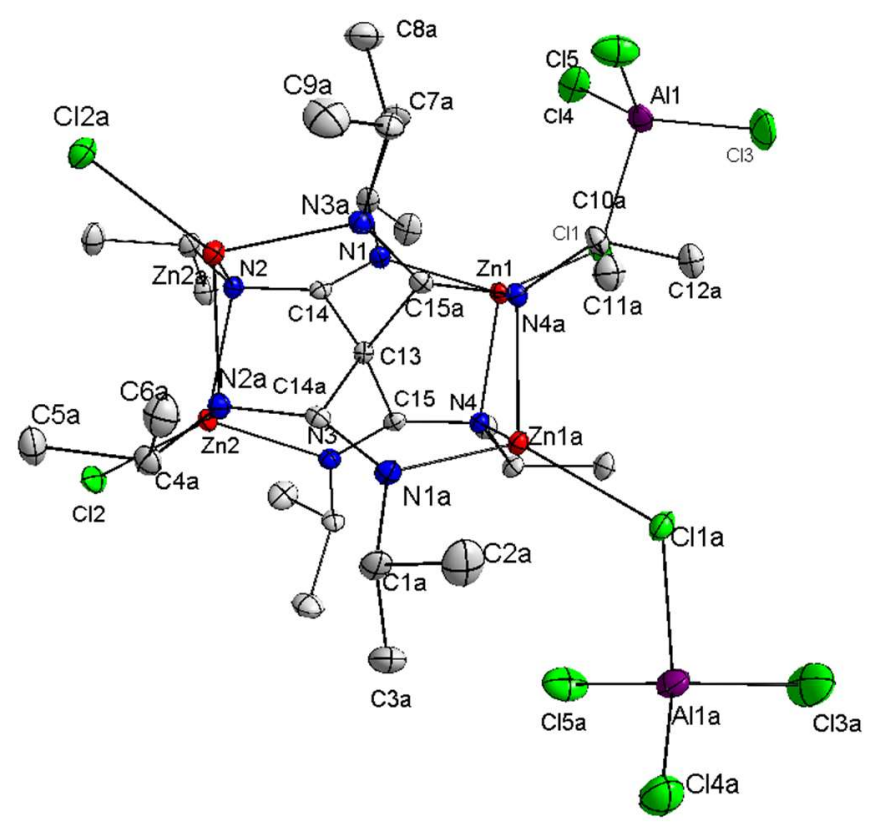


Figure 4. Solid state structure of 4 (thermal ellipsoids are shown at $50 \%$ probability levels); $\mathrm{H}$ atoms are omitted for clarity. Selected bond lengths $[\AA]$ and angles $\left[{ }^{\circ}\right]$ : Zn1-Cl1 2.2732(5), Zn2-Cl2 2.1571(5), Zn1-N1 2.0523(17), Zn1-N4 2.0968(18), Zn1-N4a 2.1052(18), Zn2-N3 2.1009(17), Zn2-N2a 2.1494(18), Zn2-N2 2.1060(17), Al1-Cl1 2.2814(9), Al1-Cl3 2.0978(10), N4-C14 1.309(3), C13-C14a 1.570(2), C13-C15 1.573(2); N1Zn1-N4a 104.43(7), N1-Zn1-N4 98.92(7), Cl1-Al1-Cl3 101.32(4), Cl3Al1-Cl5 115.40(2), N2-C14-N1 136.90(19), C14-C13-C15 98.25(10), C14a-C13-C15 101.78(10), C15-C13-C15a 130.8(2), C14-C13-C14a 130.7(2). a: $-x+1, y,-z+3 / 2$

Single crystals of $\mathbf{4}$ and $\mathbf{5}$ suitable for single crystal X-ray diffraction studies were obtained from solutions in toluene. Both complexes are isostructural and crystallize in the orthorhombic space group Pbcn. The central structural parameters such as $\mathrm{Zn}-\mathrm{N}$, $\mathrm{C}-\mathrm{N}$ and $\mathrm{C}-\mathrm{C}$ bond lengths as well as N-C-N, C-C-C and N-Zn-N bond angles are almost unchanged compared to the starting complex $\left\{[\mathrm{ClZn}]_{4}\left[\mathrm{C}(i-\mathrm{PrNCN} i-\mathrm{Pr})_{4}\right]\right\}$. In contrast, the $\mathrm{Zn}-\mathrm{Cl}$ bond lengths differ significantly from each other. While those of the terminal bonded $\mathrm{Cl} 2$ atoms $(2.1571(5) \AA 4$; 2.1564(6) $\AA$ 5) are comparable to the $\mathrm{Zn}-\mathrm{Cl}$ bond length reported for $\left\{[\mathrm{ClZn}]_{4}[\mathrm{C}(i-\right.$ $\operatorname{PrNCN} i$-Pr) $\left.\left.)_{4}\right]\right\}$ (av. value $2.172 \AA$ ), ${ }^{15}$ the bridging $\mathrm{Cl} 1$ atoms show both significantly longer $\mathrm{Zn}-\mathrm{Cl}(2.2732(5) \AA \AA$; $2.2643(6) \AA 5$ ) and $\mathrm{M}-\mathrm{Cl}$ bond lengths (Al(1)-Cl(1) 2.2814(9) $\AA$ 4; $\mathrm{Ga}(1)-\mathrm{Cl}(1)$ $2.3389(6) \AA 5$ ) compared to the average value of the remaining three terminal $\mathrm{M}-\mathrm{Cl}$ bond lengths $\left(\mathrm{Al}^{-} \mathrm{Cl}_{\text {term. }}\right.$. 2.1013(6) $\AA$ 4; 2.1342(7) $\AA$ 5). A similar bond length difference between terminal and bridging $\mathrm{M}-\mathrm{Cl}$ bonds was previously reported for

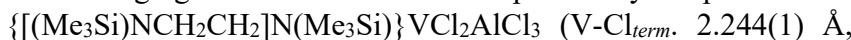
$\left.\mathrm{V}-C l_{\text {bridg. }} 2.4649(1)\right)^{[17]}$ and $\mathrm{Cp}_{2} \mathrm{ZrCl}\left(\mathrm{AlCl}_{4}\right)\left(\mathrm{Zr}-\mathrm{Cl}_{\text {term }} 2.406(3) \AA\right.$, $\left.\mathrm{Zr}-\mathrm{Cl}_{\text {bridg. }} 2.605(2) \AA\right),{ }^{[18]}$ in which the $\mathrm{AlCl}_{3}$ moieties were considered as $\left[\mathrm{AlCl}_{4}\right]^{-}$anions, that loosely coordinate to the cationic metal moiety. However, $\mathbf{4}$ and $\mathbf{5}$ rather form donoracceptor complexes since the bridging $\mathrm{M}-\mathrm{Cl}$ bond lengths $(\mathrm{M}=\mathrm{Al}$, $\mathrm{Ga})$ are significantly elongated compared to $\mathrm{M}-\mathrm{Cl}$ distances typically observed for tetrachloroaluminates (Al-Cl 2.069-2.149 $\AA$ ) and -gallanates (Ga-Cl 2.121-2.195 $\AA$ ) ${ }^{[19]}$ Moreover, the Cl-M-Cl angles as observed in $\mathbf{4}$ and $\mathbf{5}$ also differ significantly from ideal tetrahedral geometry as would be expected for $\mathrm{MCl}_{4}^{-}$anions (av. $\mathrm{Cl}_{\text {term. }}$-Al-Cl bridg. $_{103.8^{\circ},} \quad \mathrm{Cl}_{\text {term. }}$-Al-Cl term. $_{\text {. }} \quad 114.5^{\circ} \quad \mathbf{4} ; \quad \mathrm{Cl}-\mathrm{Ga}-$ $\left.\mathrm{Cl}_{\text {bridg. }} 103.1^{\circ}, \mathrm{Cl}_{\text {term. }}-\mathrm{Ga}-\mathrm{Cl}_{\text {term. }} .115 .0^{\circ} \mathbf{5}\right)$.

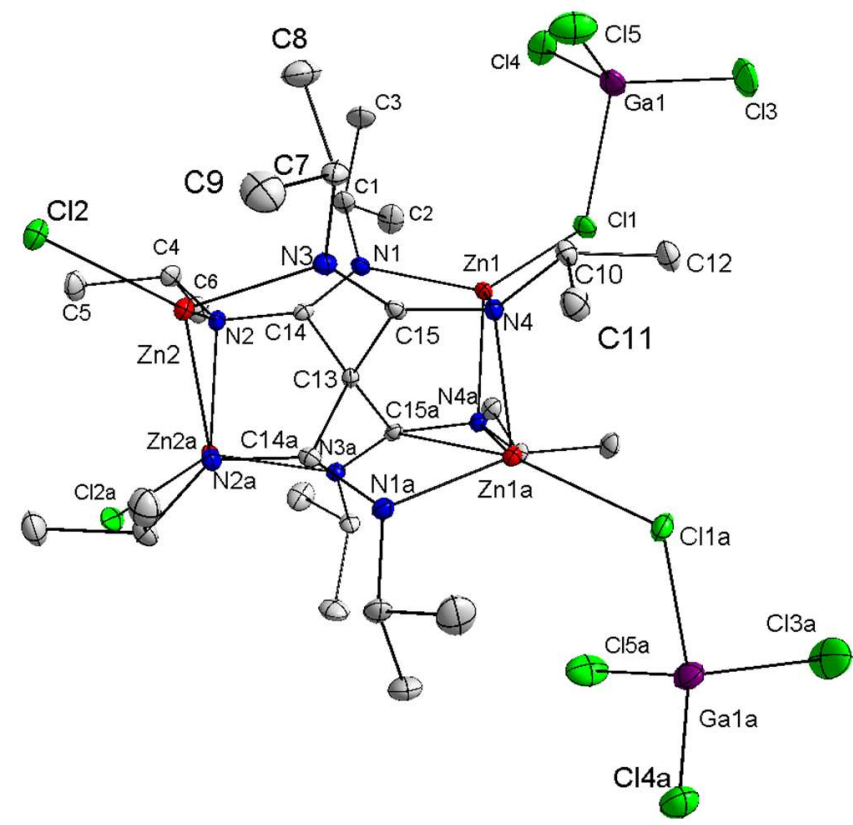

Figure 5. Solid state structure of 5 (thermal ellipsoids are shown at $50 \%$ probability levels); $\mathrm{H}$ atoms are omitted for clarity. Selected bond lengths
$[\AA]$ and angles $\left[{ }^{\circ}\right]: \mathrm{Zn} 1-\mathrm{Cl} 12.2643(6), \quad \mathrm{Zn} 2-\mathrm{Cl} 2 \quad 2.1564(6), \quad \mathrm{Zn} 1-\mathrm{N} 1$ 2.0521(18), Zn1-N4 2.0984(18), Zn1-N4a 2.1055(17), Zn2-N3 2.0972(18), Zn2-N2a 2.1454(17), Zn2-N2 2.1066(18), Ga1-Cl1 2.3389(6), Ga1-Cl3 2.1322(7), C13-C14 1.567(2), C13-C15 1.571(2); N1-Zn1-N4a 104.14(7), N1-Zn1-N4 98.88(7), Cl1-Ga1-Cl3 100.60(3), Cl3-Ga1-Cl4 114.57(3), N2C14- 136.81(19), C14-C13-C15 98.47(10), C14a-C13-C15 101.50(10), C15-C13-C15a 130.7(2), C14a-C13-C14 130.9(2). a: -x+1,y,-z+3/2

According to these structural findings, $\mathbf{4}$ and $\mathbf{5}$ are best described as Lewis acid-base adducts, which still show significant attractive interactions between the $\mathrm{Zn}$ and the $\mathrm{Cl}$ atoms. Several attempts to coordinate additional $\mathrm{MX}_{3}$ Lewis acids to the two terminal bonded $\mathrm{Cl}$ atoms failed. In these reactions, which were performed with up to a fivefold excess of $\mathrm{MX}_{3}$, colorless solids precipitated which were completely insoluble in both coordinating and noncoordinating organic solvents.

\section{Conclusions}

Cluster-type zinc amidinate complexes $\mathbf{1}$ - $\mathbf{3}$ were obtained from reactions of $\mathrm{ZnMe}_{2}$ and the corresponding carbodiimides. These reactions were found to be strongly favored by small organic substituents bound to the $\mathrm{N}$-atoms of the carbodiimide. Moreover, carbodiimides containing electron withdrawing groups at the Natoms more selectively form the tetranuclear complex in even shorter reaction times as was observed for the synthesis of $\mathbf{3}$. Unfortunately, complexes $\mathbf{1}$ and $\mathbf{3}$ failed to react with aluminum trihalides with formation of halide-substituted complexes $\left\{[\mathrm{ClZn}]_{4}\left[\mathrm{C}(\mathrm{RNCNR})_{4}\right]\right\}$. Complexes of this type are promising starting reagents for the synthesis of cationic complexes as was shown in reactions of $\left\{[\mathrm{ClZn}]_{4}\left[\mathrm{C}(i-\mathrm{PrNCN} i-\mathrm{Pr})_{4}\right]\right\}$ with $\mathrm{AlCl}_{3}$ an $\mathrm{GaCl}_{3}$, yielding Lewis acid-base adducts of the type $\left\{\left[\mathrm{MCl}_{3}\right]_{2}[\mathrm{ClZn}]_{4}\left[\mathrm{C}(i-\mathrm{PrNCN} i-\mathrm{Pr})_{4}\right]\right\} \quad(\mathrm{M}=\mathrm{Al}$ 4, Ga 5). Further reactions on the synthesis of cationic zinc complexes are currently under investigation.

\section{Experimental Section}

General Procedures. All manipulations were performed under an $\mathrm{Ar}$ atmosphere. Solvents were carefully dried over $\mathrm{Na} / \mathrm{K}$ and degassed prior to use. $\mathrm{ZnMe}_{2}$ (1.2 $\mathrm{M}$ in toluene) was purchased from Acros and used as received and $\mathrm{EtN}=\mathrm{C}=\mathrm{NEt},{ }^{20} \mathrm{PhN}=\mathrm{C}=\mathrm{NPh}^{21}$ and $\left\{[\mathrm{ClZn}]_{4}[\mathrm{C}(i-\mathrm{PrNCN} i\right.$ Pr $\left.\left.)_{4}\right]\right\}^{16}$ were prepared according to literature methods. ${ }^{1} \mathrm{H}$ and ${ }^{13} \mathrm{C}\left\{{ }^{1} \mathrm{H}\right\}$ NMR spectra were recorded on Bruker DMX 300 spectrometer and are referenced to internal $\mathrm{C}_{6} \mathrm{D}_{5} \mathrm{H}\left({ }^{1} \mathrm{H}: \delta=7.154 ;{ }^{13} \mathrm{C}: \delta=128.0\right)$. IR spectra were recorded on a ALPHA-T FT-IR spectrometer equipped with a single reflection ATR sampling module. Melting points were measured in sealed capillaries and were not corrected. Elemental analyses were performed at the Elementaranalyse Labor of the University of Essen

$\left\{[\mathrm{MeZn}]_{4}\left[\mathbf{C}(\text { EtNCNEt })_{4}\right]\right\}$ 1: $0.48 \mathrm{~g}(5 \mathrm{mmol}) \mathrm{ZnMe}_{2}$ and $1.03 \mathrm{~g}(5 \mathrm{mmol})$ $\mathrm{C}(\mathrm{NEt})_{2}$ were stirred for $2 \mathrm{~d}$ at $90{ }^{\circ} \mathrm{C}$, yielding a colorless solid, which was suspended in $30 \mathrm{~mL}$ of $n$-pentane and filtered. The filtrate was stored at $30^{\circ} \mathrm{C}$, yielding colorless 1 within $12 \mathrm{~h}$. The pentane-insoluble residue was dissolved in toluene and stored at $-30{ }^{\circ} \mathrm{C}$, yielding colorless 2 within $24 \mathrm{~h}$ $\left.[\boldsymbol{t} \text {-BuC(Ni-Pr) })_{2}\right] \mathbf{S b C l}_{2} \mathbf{1}$. Yield (isolated crystals) $0.51 \mathrm{~g} \mathrm{(56 \% ).} \mathrm{Melting}$ point: $>220^{\circ} \mathrm{C}$. Elemental Analysis $\mathrm{C}_{25} \mathrm{H}_{52} \mathrm{~N} 8 \mathrm{Zn} 4(726.23 \mathrm{~g} / \mathrm{mol})$ : found (calcd): H, 7.2 (7.2); C, 41.3 (41.3); N, 15.3 (15.4). ${ }^{1} \mathrm{H}$ NMR (500 MHz, $\left.\mathrm{C}_{6} \mathrm{D}_{6}, 25^{\circ} \mathrm{C}\right): \delta=-0.23(\mathrm{~s}, 3 \mathrm{H}, \mathrm{ZnMe}), 0.89\left(\mathrm{tr}, 3 \mathrm{H}, \mathrm{CH}_{3}\right), 1.36(\mathrm{tr}, 3 \mathrm{H}$, $\left.\mathrm{CH}_{3}\right), 3.29$ (q, 2H, $\mathrm{CH}_{2}$ ), 3.30 (q, 2H, CH$\left.H_{2}\right) .{ }^{13} \mathrm{C}\left\{{ }^{1} \mathrm{H}\right\} \mathrm{NMR}\left(125 \mathrm{MHz}, \mathrm{C}_{6} \mathrm{D}_{6}\right.$, $\left.25^{\circ} \mathrm{C}\right): \delta=-14.3(\mathrm{~s}, \mathrm{ZnMe}), 17.0\left(\mathrm{CH}_{3}\right), 18.1\left(\mathrm{CH}_{3}\right), 41.9\left(\mathrm{CH}_{2}\right), 43.4$ $\left(\mathrm{CH}_{2}\right), 172.3(\mathrm{NCN}) . \mathrm{IR}: v=2966,2928,2862,2829,583,1548,1478$, $1446,1377,1329,1296,1263,1133,1102,1040,984,901,863,818,771$, $669,648,524,493,434 \mathrm{~cm}^{-1}$. 
$\left\{[\mathbf{M e Z n}]_{2}\left[\mathbf{C}(\mathbf{E t N C N E t})_{2}\left(\mathbf{C}_{2}(\mathbf{N E t})_{3}\right)\right]\right\}$ 2: $4.2 \mathrm{ml} \mathrm{ZnMe}{ }_{2}(1.2 \mathrm{M}$ in toluene, 5 $\mathrm{mmol})$ and $2.06 \mathrm{~g}(10 \mathrm{mmol})$ purified $(\mathrm{EtN}) 2 \mathrm{C}$ were stirred for $5 \mathrm{~d}$ at $110^{\circ} \mathrm{C}$. All volatiles were removed at reduced pressure and the resulting solid was dissolved in $30 \mathrm{~mL}$ hexane and stored at $0{ }^{\circ} \mathrm{C}$. Colorless crystals of 2 were formed within $24 \mathrm{~h}$ and isolated by filtration.

Yield (isolated crystals) $0.61 \mathrm{~g}(47 \%)$. Melting point: $118^{\circ} \mathrm{C}$. Elemental Analysis $\mathrm{C}_{21} \mathrm{H}_{41} \mathrm{~N} 7 \mathrm{Zn} 2(522.35 \mathrm{~g} / \mathrm{mol})$ : found (calcd): H, 8.13 (7.91); C, 48.56 (48.29); N, 18.23 (18.77). ${ }^{1} \mathrm{H}$ NMR $\left(500 \mathrm{MHz}, \mathrm{C}_{6} \mathrm{D}_{6}, 25^{\circ} \mathrm{C}\right): \delta=-$ 0.07 (s, $6 \mathrm{H}, \mathrm{ZnMe}$ ), 0.32 (t, $\left.3 \mathrm{H}, \mathrm{CH}_{2} \mathrm{CH}_{3}\right), 1.23\left(\mathrm{t}, 6 \mathrm{H}, \mathrm{CH}_{2} \mathrm{CH}_{3}\right), 1.30$ (t, $12 \mathrm{H}, \mathrm{CH}_{2} \mathrm{CH}_{3}$ ), 2.40 (q, 2H, $\mathrm{CH}_{2} \mathrm{CH}_{3}$ ), 3.03 (q, 4H, $\mathrm{CH}_{2} \mathrm{CH}_{3}$ ), 3.64 (q, 8H, $\left.\mathrm{CH}_{2} \mathrm{CH}_{3}\right) .{ }^{13} \mathrm{C}\left\{{ }^{1} \mathrm{H}\right\}$ NMR $\left(125 \mathrm{MHz}, \mathrm{C}_{6} \mathrm{D}_{6}, 25^{\circ} \mathrm{C}\right): \delta=-14.8(\mathrm{ZnMe}), 16.2$ $\left(\mathrm{CH}_{2} \mathrm{CH}_{3}\right), 17.1\left(\mathrm{CH}_{2} \mathrm{CH}_{3}\right), 19.3\left(\mathrm{CH}_{2} \mathrm{CH}_{3}\right), 30.5\left(\mathrm{CH}_{2} \mathrm{CH}_{3}\right), 41.8\left(\mathrm{CH}_{2} \mathrm{CH}_{3}\right)$, $42.9\left(\mathrm{CH}_{2} \mathrm{CH}_{3}\right)$. Resonances of the $\mathrm{NCN}$ unit were not observed due to the limited solubility of $\mathbf{2}$ in organic solvents. ATR-IR: $v=2963,2925,2890$, 2822, 1694, 1572, 1474, 1443, 1376, 1320, 1261, 1155, 1099, 1031, 967, $801,637,609,518,436 \mathrm{~cm}^{-1}$.

$\left\{[\mathbf{M e Z n}]_{4}\left[\mathbf{C}(\mathbf{P h N C N P h})_{4}\right]\right\}$ 3: $0.48 \mathrm{~g}(5 \mathrm{mmol}) \mathrm{ZnMe}_{2}$ and $0.97 \mathrm{~g}(5$ mmol) $\mathrm{C}(\mathrm{NPh}) 2$ were stirred for $2 \mathrm{~d}$ at $90{ }^{\circ} \mathrm{C}$. The resulting solid was dissolved in $30 \mathrm{~mL}$ of toluene and stored at $-30{ }^{\circ} \mathrm{C}$, yielding colorless crystals of 3 within $12 \mathrm{~h}$.

Yield $1.33 \mathrm{~g} \mathrm{(96 \% ).} \mathrm{Melting} \mathrm{point:}>220^{\circ} \mathrm{C}$. Elemental Analysis $\mathrm{C}_{57} \mathrm{H}_{52} \mathrm{~N} 8 \mathrm{Zn} 4$ (1110.58 g/mol): found (calcd): H, 4.6 (4.7); C, 61.6 (61.6); $\mathrm{N}, 10.1(10.1) .{ }^{1} \mathrm{H}$ NMR $\left(500 \mathrm{MHz}, \mathrm{C}_{6} \mathrm{D}_{6}, 25^{\circ} \mathrm{C}\right): \delta=-0.29$ (s, $\left.12 \mathrm{H}, \mathrm{ZnMe}\right)$, 6.56-7.15 (m, 40H,Ph) ${ }^{13} \mathrm{C}\left\{{ }^{1} \mathrm{H}\right\}$ NMR $\left(125 \mathrm{MHz}, \mathrm{C}_{6} \mathrm{D}_{6}, 25^{\circ} \mathrm{C}\right): \delta=-14.5$ $(\mathrm{ZnMe}), 123.7(P h), 123.7(P h), 124.3(P h), 128.5(P h), 128.5(P h), 144.4$ $(P h), 144.7(P h), 169.5$ (s, NCN). IR: $v=3068,3028,2962,2906,2844$, 1594, 1554, 1519 1485, 1449, 1330, 1259, 1071, 1021, 925, 797, 755, 728, $686,595,542,512,463,417,404 \mathrm{~cm}^{-1}$.

$\left\{\left[\mathbf{M C l}_{3}\right]_{2}[\mathbf{C l Z n}]_{4}\left[\mathbf{C}(\boldsymbol{i}-\mathbf{P r N C N i}-\mathbf{P r})_{4}\right]\right\}(\mathbf{M}=\mathbf{A l} 4, \mathbf{G a} 5): 0.5 \mathrm{~g}(0.54 \mathrm{mmol})$ $\left\{[\mathrm{ClZn}]_{4}\left[\mathrm{C}(i \text {-PrNCNi}-\mathrm{Pr})_{4}\right]\right\}$ and $1.08 \mathrm{mmol} \mathrm{MCl}_{3}(\mathrm{M}=\mathrm{Al}, 0.14 \mathrm{~g}$; $\mathrm{Ga} 0.32$ g) were dissolved in $15 \mathrm{ml}$ toluene and stirred for $1 \mathrm{~h}$ at $100^{\circ} \mathrm{C}$. Colorless crystals of $\mathbf{4}$ and $\mathbf{5}$ formed within $24 \mathrm{~h}$ upon slow cooling to room temperature.

$\left\{\left[\mathrm{AlCl}_{3}\right]_{2}[\mathbf{C l Z n}]_{4}\left[\mathbf{C}(\boldsymbol{i} \text {-PrNCNi-Pr) })_{4}\right]\right\}$ 4: Yield (isolated crystals): $0.56 \mathrm{~g}$ (87\%). Melting point: $>250{ }^{\circ} \mathrm{C}$. Elemental Analysis $\mathrm{C}_{29} \mathrm{H}_{56} \mathrm{~N}_{8} \mathrm{Zn}_{4} \mathrm{Cl}_{10} \mathrm{Al}_{2}$ (1186.94 g/mol): found (calcd): H, 4.63 (4.75); C, 29.12 (29.34); N, 9.21 (9.44). ${ }^{1} \mathrm{H} \mathrm{NMR}\left(300 \mathrm{MHz}, \mathrm{C}_{6} \mathrm{D}_{6}, 25^{\circ} \mathrm{C}\right): \delta 1.15\left(\mathrm{~d}, 24 \mathrm{H},{ }^{3} \mathrm{~J}_{H H}=6.4 \mathrm{~Hz}\right.$, $\left.\mathrm{CH}\left(\mathrm{CH}_{3}\right)_{2}\right), 1.24\left(\mathrm{~d}, 24 \mathrm{H},{ }^{3} \mathrm{~J}_{\mathrm{HH}}=6.4 \mathrm{~Hz}, \mathrm{CH}\left(\mathrm{CH}_{3}\right)_{2}\right), 3.72$ (sept, $4 \mathrm{H},{ }^{3} J_{H H}=$ $\left.6.4 \mathrm{~Hz}, \mathrm{CH}\left(\mathrm{CH}_{3}\right)_{2}\right), 3.93$ (sept, $\left.4 \mathrm{H},{ }^{3} \mathrm{~J}_{\mathrm{HH}}=6.4 \mathrm{~Hz}, \mathrm{CH}\left(\mathrm{CH}_{3}\right)_{2}\right) .{ }^{13} \mathrm{C}\left\{{ }^{1} \mathrm{H}\right\}$ NMR (200 MHz, $\left.\mathrm{C}_{6} \mathrm{D}_{6}, 25^{\circ} \mathrm{C}\right): \delta 23.9\left(\mathrm{CH}\left(\mathrm{CH}_{3}\right)_{2}\right), 24.4\left(\mathrm{CH}\left(\mathrm{CH}_{3}\right)_{2}\right), 49.5$ $\left(\mathrm{CH}\left(\mathrm{CH}_{3}\right)_{2}\right), 50.6\left(\mathrm{CH}\left(\mathrm{CH}_{3}\right)_{2}\right), 71.8(\mathrm{CC} 4), 169.4(\mathrm{NCN})$. ATR-IR: $v 2967$, 2932, 2905, 2875, 1562, 1533, 1451, 1391, 1372, 1327, 1305, 1255, 1235, $1121,1083,1017,871,786,732,694,669,538,526,472 \mathrm{~cm}^{-1}$.

$\left\{\left[\mathbf{G a C l}_{3}\right]_{2}[\mathbf{C I Z n}]_{4}\left[\mathbf{C}(\boldsymbol{i}-\mathbf{P r N C N i} \mathbf{- P r})_{4}\right]\right\}$ 5: Yield (isolated crystals): $0.51 \mathrm{~g}$ (74\%). Melting point: $>250^{\circ} \mathrm{C}$ (dec.). Elemental Analysis $\mathrm{C}_{29} \mathrm{H}_{56} \mathrm{Ga}_{2} \mathrm{Cl}_{10} \mathrm{~N}_{8} \mathrm{Zn}_{4}$ (1272.27 g/mol): found (calcd): $\mathrm{H}, 4.38$ (4.44); $\mathrm{C}$, 26.68 (27.38); N, 8.64 (8.81). ${ }^{1} \mathrm{H}$ NMR ( $\left.300 \mathrm{MHz}, \mathrm{C}_{6} \mathrm{D}_{6}, 25^{\circ} \mathrm{C}\right): \delta 1.16(\mathrm{~d}$, $\left.24 \mathrm{H},{ }^{3} J_{H H}=6.4 \mathrm{~Hz}, \mathrm{CH}\left(\mathrm{CH}_{3}\right)_{2}\right), 1.30\left(\mathrm{~d}, 24 \mathrm{H},{ }^{3} \mathrm{~J}_{\mathrm{HH}}=6.4 \mathrm{~Hz}, \mathrm{CH}\left(\mathrm{CH}_{3}\right)_{2}\right)$, 3.71 (sept, $\left.4 \mathrm{H},{ }^{3} J_{H H}=6.4 \mathrm{~Hz}, \mathrm{CH}\left(\mathrm{CH}_{3}\right)_{2}\right), 3.96$ (sept, $4 \mathrm{H},{ }^{3} J_{H H}=6.4 \mathrm{~Hz}$, $\left.\mathrm{CH}\left(\mathrm{CH}_{3}\right)_{2}\right) \cdot{ }^{13} \mathrm{C}\left\{{ }^{1} \mathrm{H}\right\}$ NMR $\left(200 \mathrm{MHz}, \mathrm{C}_{6} \mathrm{D}_{6}, 25^{\circ} \mathrm{C}\right): \delta 23.8\left(\mathrm{CH}\left(\mathrm{CH}_{3}\right)_{2}\right)$, $24.4\left(\mathrm{CH}\left(\mathrm{CH}_{3}\right)_{2}\right), 49.3\left(\mathrm{CH}\left(\mathrm{CH}_{3}\right)_{2}\right), 50.6\left(\mathrm{CH}\left(\mathrm{CH}_{3}\right)_{2}\right), 71.9(\mathrm{CC} 4), 169.5$ (NCN). ATR-IR: v 2974, 2932, 2875, 1558, 1530, 1511, 1451, 1391, 1372, $1267,1229,1121,1071,931,890,868,814,732,694,647,583,520,463$, $409 \mathrm{~cm}^{-1}$.

Single crystal X-ray analyses. Crystallographic data of $\mathbf{1}-\mathbf{5}$, which were collected on a Bruker AXS D8 Kappa diffractometer $\left(\mathrm{Mo}_{\mathrm{K} \alpha}\right.$ radiation, $\lambda=$ $0.71073 \AA$ ), are summarized in Table 1. Figures $1-5$ show diagrams of the solid-state structure of $\mathbf{1}$ - $\mathbf{5}$. The structures were solved by Direct Methods (SHELXS-97) 22 and refined by full-matrix least-squares on $\mathrm{F}^{2}$. Absorption corrections were performed semi-empirically from equivalent reflections on basis of multi-scans (Bruker AXS APEX2). All non-hydrogen atoms were refined anisotropically and hydrogen atoms by a riding model (SHELXL-97, Program for Crystal Structure Refinement ${ }^{23}$ on idealized geometries with the 1.2 fold (1.5 fold for methyl groups) isotropic displacement parameters of the equivalent $U i j$ of the corresponding carbon atom. The crystal of $\mathbf{2}$ was racemically twinned and refined accordingly. 3 contained a toluene molecule disordered over two positions. The phenyl rings were constrained to regular hexagons. $\mathbf{4}$ und $\mathbf{5}$ contained 1.5 toluene molecules severely disordered over a two-fold axis. The half occupied one was constrained to a regular hexagon and refined with fixed $U$ and without hydrogen atoms. The methyl hydrogen atoms of the fully occupied toluene were refined as idealized disorder with two positions rotated from each other about $60^{\circ}$.

Supporting Information: The crystallographic data of $\mathbf{1}-\mathbf{5}$ (excluding structure factors) have been deposited with the Cambridge Crystallographic Data Centre as supplementary publication nos. CCDC-794409 (1), CCDC794408 (2), CCDC-794412 (3), CCDC-826704 (4), CCDC-826705 (5). Copies of the data can be obtained free of charge on application to CCDC, 12 Union Road, Cambridge, CB21EZ (fax: (+44) 1223/336033; e-mail: deposit@ccdc.cam-ak.uk).

\section{Acknowledgments}

S. Schulz thanks the German Science Foundation (DFG) for financial support.

[1] For recent review articles see: a) L. Bourget-Merle, M. F. Lappert, J. R. Severn, Chem. Rev. 2002, 102, 3031; b) W. E. Piers, D. J. H. Emslie, Coord. Chem. Rev. 2002, 233, 131; c) H. W. Roesky, S Singh, V. Jancik, V. Chandrasekhar, Acc. Chem. Res. 2004, 37, 969; d) D. J. Mindiola, Acc. Chem. Res. 2006, 39, 813; e) C. J. Cramer, W. B. Tolman, Acc. Chem. Res. 2007, 40, 601; f) P. L. Holland, Acc. Chem. Res. 2008, 41, 905.

[2] P. J. Bailey, S. Pace, Coord. Chem. Rev. 2001, 214, 91; b) F. T. Edelmann, Chem. Soc. Rev. 2009, 38, 2253; c) D. A. Kissounko, M V. Zabalov, G. P. Brusova, D. A. Lemenovskii, Russ. Chem. Rev 2006, $75,351$.

[3] a) J. Barker, M. Kilner, Coord. Chem. Rev. 1994, 133, 219; b) P. C. Junk, M. L. Cole, J. Chem. Soc., Chem. Commun. 2007, 1579; c) F. T. Edelmann, Adv. Organomet. Chem. 2008, 57, 183.

[4] Coordination complexes of neutral amidines and guanidines have been reviewed recently: M. P. Coles, J. Chem. Soc., Dalton Trans. 2006, 985.

[5] a) C. E. Radzewich, M. P. Coles, R. F. Jordan J. Am. Chem. Soc. 1998, 120, 9384; b) S. Dagorne, I. A. Guzei, M. P. Coles, R. F. Jordan, J. Am. Chem. Soc. 2000, 122, 274; c) S. Bambirra, M. W. Bouwkamp, A. Meetsma, B. Hessen, J. Am. Chem. Soc. 2004, 126, 9182. For most recent review articles see: d) S. Dagorne, D. A. Atwood, Chem. Rev. 2008, 108, 4037; e) M. Nishiura, Z. Hou, Nature Chem. 2010, 2, 257.

[6] a) A. Baunemann, D. Bekermann, T. B. Thiede, H. Parala, M Winter, C. Gemel, R. A. Fischer, J. Chem. Soc., Dalton Trans. 2008 3715; b) J. P. Coyle, W. H. Monillas, G. P. A. Yap, S. T. Barry, Inorg. Chem. 2008, 47, 683; c) A. L. Brazeau, S. T. Barry, Chem. Mater. 2008, 20, 7287; d) J. P. Coyle, P. A. Johnson, G. A. DiLabio, S. T. Barry, J. Müller, Inorg. Chem. 2010, 49, 2844; e) Y. A. Wasslen, E. Tois, S. Haukka, K. A. Kreisel, G. P. A. Yap, M. D. Halls, S. T. Barry, Inorg. Chem. 2010, 49, 1976.

[7] a) J.-K. Buijink, M. Noltemeyer, F. T. Edelmann, Z. Naturforsch. B 1991, 46, 1328; b) F. A. Cotton, L. M. Daniels, L. R. Falvello, J. H. Matonic, C. A. Murillo, X. Wang, H. Zhou, Inorg. Chim. Acta 1997, 266, 91; c) M. L. Cole, D. J. Evans, P. C. Junk, L. M. Louis, New J. Chem. 2002, 26, 1015; d) T. Chivers, D. J. Eisler, C. Fedorchuk, G. Schatte, H. M. Tuononen, Inorg. Chem. 2006, 45, 2119; e) C. Fedorchuk, M. Copsey, T. Chivers, Coord. Chem. Rev. 2007, 251, 897.

[8] See the following and reference cited therein: a) M. P. Coles, $J$ Chem. Soc., Chem. Commun. 2009, 3659; b) J. J. Ng, C. B. Durr, J. M. Lance, S. D. Bunge, Eur. J. Inorg. Chem. 2010, 1424; c) M. Reinmuth, C. Neuhäuser, P. Walter, M. Enders, E. Kaifer, H.-J. Himmel, Eur. J. Inorg. Chem. 2011, 83. 
[9] See the following and reference cited therein: a) M. Cheng, A. B. Attygalle, E. B. Lobkovsky, G. W. Coates, J. Am. Chem. Soc. 1999, 121,11583 ; b) M. Cheng, D. R. Moore, J. J. Reczek, B. M. Chamberlain, E. B. Lobkovsky, G. W. Coates, J. Am. Chem. Soc 2001, 123, 8738; c) D. R. Moore, M. Cheng, E. B. Lobkovsky, G. W. Coates, Angew. Chem. 2002, 114, 2711; Angew. Chem. Int. Ed. 2004 41, 2599; d) L. R. Rieth, D. R. Moore, E. B. Lobkovsky, G. W. Coates, J. Am. Chem. Soc. 2002, 124, 15239; e) D. R. Moore, M. Cheng, E. B. Lobkovsky, G. W. Coates, J. Am. Chem. Soc. 2003 125, 11911; f) G. W. Coates, D. R. Moore Angew. Chem. 2004, 116 6784; Angew. Chem. Int. Ed. 2004, 43, 6618; g) J. Wu, T.-L. Yu, C.T. Chen, C.-C. Lin, Coord. Chem. Rev. 2006, 250, 602; h) D. F.-J. Piesik, S. Range, S. Harder Organometallics 2008, 27, 6178; i) R. C. Jeske, J. M. Rowley, G. W. Coates Angew. Chem. 2008, 120, 2711; Angew. Chem. Int. Ed. 2008, 47, 6041; j) F. Drouin, P. O Oguadinma, T. J. J. Whitehorne, R. E. Prud'homme, F. Schaper, Organometallics 2010, 29, 2139.

[10] a) T. Eisenmann, J. Khanderi, S. Schulz, U. Flörke, Z. Anorg. Allg. Chem. 2008, 634, 507; b) S. Schmidt, S. Schulz, M. Bolte, Z. Anorg. Allg. Chem. 2009, 635, 2210.

[11] Carbodiimides readily undergo insertion reactions into metal-carbon and metal-nitrogen bonds of main group metals, transition metals and lanthanides and actinides. See the following and references cited therein: a) A. L. Brazeau, G. A. DiLabio, K. A. Kreisel, W. Monillas, G. P. A. Yap, S. T. Barry, J. Chem. Soc., Dalton Trans. 2007, 3297; b) C. N. Rowley, T.-G. Ong, J. Priem, T. K. Woo, D. S. Richeson, Inorg. Chem. 2008, 47, 9660; c) W.-X. Zhang, D. Li, Z. Wang, Z. Xi, Organometallics 2009, 28, 882; d) C. Pi, X. Li, L. Zhang, R. Liu, L. Weng, X. Zhou, Inorg. Chem. 2010, 49, 7632; e) F. T. Edelmann, Struct. Bond. 2010, 137, 109.

[12] S. Schulz, M. Münch, U. Flörke, Z. Anorg. Allg. Chem. 2008, 634, 2221.

[13] M. Münch, U. Flörke, M. Bolte, S. Schulz, D. Gudat, Angew. Chem., 2008, 120, 1535; Angew. Chem. Int. Ed. 2008, 47, 1512.

[14] S. Schmidt, S. Gondzik, S. Schulz, D. Blaeser, R. Boese, Organometallics 2009, 28, 4371
[15] B. Gutschank, S. Schulz, D. Blaeser, R. Boese; C. Wölper, Organometallics 2010, 29, 6133.

[16] B. Gutschank, S. Schulz, U. Westphal, D. Blaeser, R. Boese, Organometallics 2010, 29, 2093.

[17] K. Feghali, D. J. Harding, D. Reardon, S. Gambarotta, G. P. A. Yap, Organometallics 2002, 21, 968.

[18] M. V. Gaudet, J. Zawarotko, T. S. Cameron, A. Linden, J. Organomet. Chem. 1989, 367, 267.

[19] F. H. Allen, Acta Cryst. 2002, B58, 380. CSD-Search (version 5.32 update 1,2) with ConQuest (version 1.13) aiming the range of general bonding distances and angles in $\left[\mathrm{AlCl}_{4}\right]^{-}$and $\left[\mathrm{GaCl}_{4}\right]^{-}$.

[20] G. Kollenz, G. Penn, W. Ott, K. Peters, E.-M. Peters, H. J. von Schnering, Chem. Ber. 1984, 117, 1310.

[21] M. Findlater, N. J. Hill, A. H. Cowley, J. Chem. Soc., Dalton Trans. 2008, 4419 .

[22] G. M. Sheldrick, Acta Crystallogr. Sect. A 1990, 46, 467.

[23] G. M. Sheldrick, Program for Crystal structure Refinement; Universität Göttingen, 1997 (see also: G. M. Sheldrick, Acta Crystallogr. 2008, A64, 112.).

Received: ((will be filled in by the editorial staff)) Published online: ((will be filled in by the editorial staff)) 
Table 1. Crystallographic data for $\mathbf{1}-\mathbf{5}$

\begin{tabular}{|c|c|c|c|c|c|}
\hline & 1 & 2 & 3 & 4 & 5 \\
\hline empirical formula & $\mathrm{C}_{25} \mathrm{H}_{52} \mathrm{~N}_{8} \mathrm{Zn}_{4}$ & $\mathrm{C}_{21} \mathrm{H}_{41} \mathrm{~N}_{7} \mathrm{Zn}_{2}$ & $\mathrm{C}_{57} \mathrm{H}_{52} \mathrm{~N}_{8} \mathrm{Zn}_{4} *\left[\mathrm{C}_{7} \mathrm{H}_{8}\right]$ & $\begin{array}{l}\mathrm{C}_{29} \mathrm{H}_{56} \mathrm{Al}_{2} \mathrm{Cl}_{10} \mathrm{~N}_{8} \mathrm{Zn}_{4} * \\
1.5\left[\mathrm{C}_{7} \mathrm{H}_{8}\right]\end{array}$ & $\begin{array}{l}\mathrm{C}_{29} \mathrm{H}_{56} \mathrm{Ga}_{2} \mathrm{Cl}_{10} \mathrm{~N}_{8} \mathrm{Zn}_{4} \\
* 1.5\left[\mathrm{C}_{7} \mathrm{H}_{8}\right]\end{array}$ \\
\hline molecular mass & 726.23 & 522.35 & 1202.68 & 1326.93 & 1412.41 \\
\hline crystal system & triclinic & monoclinic & monoclinic & orthorhombic & orthorhombic \\
\hline space group & $\mathrm{P}-1$ & $\mathrm{P} 2_{1}$ & $\mathrm{C} 2 / \mathrm{c}$ & Pbcn & Pbcn \\
\hline $\mathrm{a}[\AA]$ & $11.7097(4)$ & $10.7283(6)$ & $22.1716(8)$ & $14.3298(9)$ & $14.3175(9)$ \\
\hline $\mathrm{b}[\AA]$ & $11.7102(4)$ & $21.1976(12)$ & $15.6427(5)$ & $19.3470(12)$ & $19.3167(12)$ \\
\hline $\mathrm{c}[\AA]$ & $11.8034(4)$ & $11.6755(7)$ & $17.4266(6)$ & $19.7439(12)$ & $19.7752(13)$ \\
\hline$\alpha[\mathrm{deg}]$ & $93.757(2)$ & 90 & 90 & 90 & 90 \\
\hline$\beta[\mathrm{deg}]$ & $92.321(2)$ & $106.564(3)$ & $110.926(2)$ & 90 & 90 \\
\hline$\gamma[\operatorname{deg}]$ & $96.337(2)$ & 90 & 90 & 90 & 90 \\
\hline $\mathrm{V}\left[\AA^{3}\right]$ & $1603.31(9)$ & $2545.0(3)$ & $5645.3(3)$ & $5473.8(6)$ & $5469.2(6)$ \\
\hline Z & 2 & 4 & 4 & 4 & 4 \\
\hline $\mathrm{T}[\mathrm{K}]$ & $103(2)$ & $100(1)$ & $103(1)$ & $100(1)$ & $100(1)$ \\
\hline radiation $\lambda[\AA]$ & 0.71073 & 0.71073 & 0.71073 & 0.71073 & 0.71073 \\
\hline$\mu\left[\mathrm{mm}^{-1}\right]$ & 2.983 & 1.906 & 1.727 & 2.290 & 3.224 \\
\hline $\mathrm{D}_{\text {calcd. }}\left[\mathrm{g} \mathrm{cm}^{-3}\right]$ & 1.504 & 1.363 & 1.415 & 1.610 & 1.715 \\
\hline $2 \theta_{\max }[\mathrm{deg}]$ & 61.2 & 50.8 & 60.1 & 56.6 & 56.7 \\
\hline cryst. $\operatorname{dim}[\mathrm{mm}]$ & $0.36 \times 0.32 \times 0.28$ & $0.27 \times 0.13 \times 0.10$ & $0.22 \times 0.18 \times 0.13$ & $0.45 \times 0.37 \times 0.28$ & $0.34 \times 0.25 \times 0.22$ \\
\hline no. of reflns. & 25594 & 20037 & 33112 & 46986 & 57651 \\
\hline no. uniq. reflns. & 9582 & 8629 & 8231 & 6713 & 6788 \\
\hline$R_{\text {merg }}$ & 0.0231 & 0.0227 & 0.0291 & 0.0234 & 0.0239 \\
\hline no. of param. ref./restraints & $334 / 0$ & $542 / 1$ & $328 / 0$ & $254 / 0$ & $254 / 0$ \\
\hline$R 1^{[\mathrm{a}]}$ & 0.0255 & 0.0284 & 0.0340 & 0.0292 & 0.0276 \\
\hline$w R 2^{[\mathrm{b}]}$ & 0.0545 & 0.0667 & 0.0968 & 0.0833 & 0.0750 \\
\hline goodness of fit ${ }^{[\mathrm{c}]}$ & 1.043 & 1.059 & 1.032 & 1.048 & 1.075 \\
\hline max./min. transmission & $0.75 / 0.56$ & $0.75 / 0.64$ & $0.75 / 0.60$ & $0.75 / 0.63$ & $0.75 / 0.44$ \\
\hline final max $/ \min . \Delta \rho, \mathrm{e} \AA^{-3}$ & $0.680 /-0.344$ & $0.690 /-0.263$ & $0.840 /-0.581$ & $1.022 /-1.002$ & $1.161 /-0.888$ \\
\hline
\end{tabular}

[a] $R 1=\Sigma\left(|| F_{\mathrm{o}}|-| F_{\mathrm{c}} \mid\right) / \Sigma\left|F_{\mathrm{o}}\right|($ for $\mathrm{I}>2 \sigma(\mathrm{I})) .-{ }^{[\mathrm{b}]} w R 2=\left\{\Sigma\left[w\left(F_{\mathrm{o}}^{2}-F_{\mathrm{c}}^{2}\right)^{2}\right] / \Sigma\left[w\left(F_{\mathrm{o}}^{2}\right)^{2}\right]\right\}^{1 / 2}$. - ${ }^{[\mathrm{c}]}$ Goodness of fit $=\left\{\Sigma\left[w\left(\left|F_{\mathrm{o}}^{2}\right|-\left|\mathrm{F}_{\mathrm{c}}^{2}\right|\right)^{2}\right] /\left(\mathrm{N}_{\mathrm{observns}}-\mathrm{N}_{\text {params }}\right)\right\}^{1 / 2} \cdot w^{-1}=$ $\sigma^{2}\left(F_{\mathrm{o}}^{2}\right)+(a P)^{2}+b P$ with $P=\left[F_{\mathrm{o}}^{2}+2 F_{\mathrm{c}}^{2}\right] / 3, a$ and $b$ are constants chosen by the programme. 
Entry for the Table of Contents

((Key Topic))

$\mathrm{C}-\mathrm{C}$ bond formation reactions between $\mathrm{ZnMe}_{2}$ and carbodiimides and Lewis acid-base adducts of a tetranuclear zinc amidinate complex.

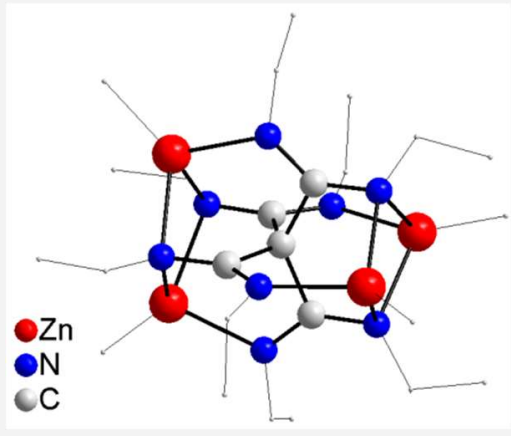

Sarah Schmidt, Benjamin Gutschank, Stephan Schulz,* Dieter Bläser,

Roland Boese, Christoph Wölper Page No. - Page No.

Synthesis and X-Ray Crystal Structures of Multinuclear Zincamidinate Complexes

Keywords: N ligands / Zinc / X-Ray crystal structure 
This text is made available via DuEPublico, the institutional repository of the University of Duisburg-Essen. This version may eventually differ from another version distributed by a commercial publisher.

DOI: $\quad 10.1002 /$ ejic.201100685

URN: urn:nbn:de:hbz:464-20201110-150841-3

This is the peer reviewed version of the following article: Eur. J. Inorg. Chem. 2011, 4464-4470, which has been published in final form at: https://doi.org/10.1002/ejic.201100685

All rights reserved. 